
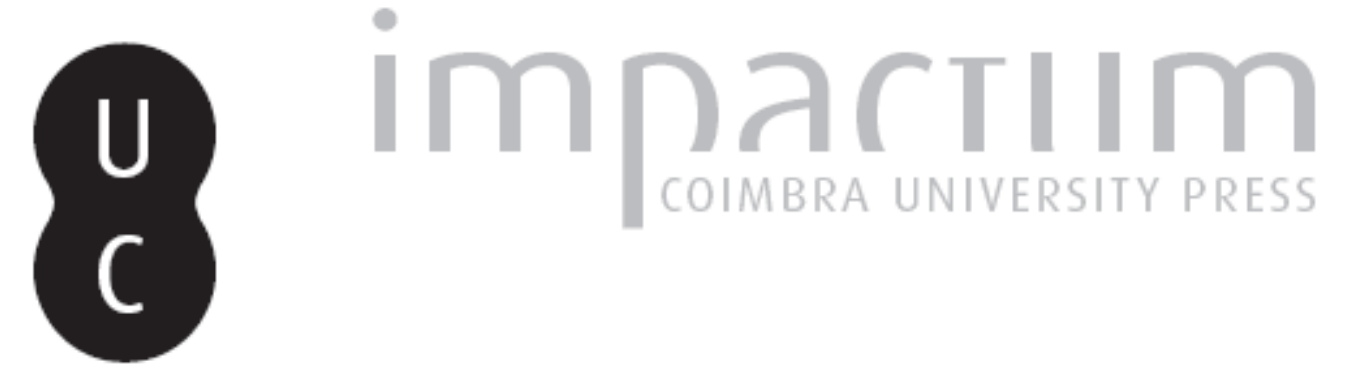

\title{
Valutazione delle lesioni dell'articolazione temporomandibolare: danni iatrogeni e traumatologici
}

\author{
Autor(es): $\quad$ Manfredini, D.; Guarda-Nardini, L.
}

Publicado por: Imprensa da Universidade de Coimbra

URL

persistente:

URI:http://hdl.handle.net/10316.2/33107

DOI:

DOI:http://dx.doi.org/10.14195/1647-8630_18_6

Accessed : $\quad$ 26-Apr-2023 14:19:09

A navegação consulta e descarregamento dos títulos inseridos nas Bibliotecas Digitais UC Digitalis, UC Pombalina e UC Impactum, pressupõem a aceitação plena e sem reservas dos Termos e Condições de Uso destas Bibliotecas Digitais, disponíveis em https://digitalis.uc.pt/pt-pt/termos.

Conforme exposto nos referidos Termos e Condições de Uso, o descarregamento de títulos de acesso restrito requer uma licença válida de autorização devendo o utilizador aceder ao(s) documento(s) a partir de um endereço de IP da instituição detentora da supramencionada licença.

Ao utilizador é apenas permitido o descarregamento para uso pessoal, pelo que o emprego do(s) título(s) descarregado(s) para outro fim, designadamente comercial, carece de autorização do respetivo autor ou editor da obra.

Na medida em que todas as obras da UC Digitalis se encontram protegidas pelo Código do Direito de Autor e Direitos Conexos e demais legislação aplicável, toda a cópia, parcial ou total, deste documento, nos casos em que é legalmente admitida, deverá conter ou fazer-se acompanhar por este aviso.

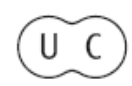




\title{
Valutazione delle lesioni dell'articolazione temporo- mandibolare: danni iatrogeni e traumatologici ${ }^{1}$
}

\author{
D. Manfredini, L. Guarda-Nardini²
}

\section{Introduction}

Pathologies of the temporomandibular joint (TMJ) belong to a wide and heterogeneous group of conditions termed temporomandibular disorders (TMD) (1).

TMJ disorders are the most frequent cause of non-dental chronic pain in the orofacial region (2), and their high prevalence has been described in several worldwide papers (3-5).

Some TMJ disorders can be the result of iatrogenic or traumatic events, thus requesting a medical legal appraisal. Therefore, a comprehension of etiopathogenetic mechanisms leading to their onset and a description of the currently available diagnostic and treatment techniques may be useful in the medical legal setting as well (6).

\section{Etiopathogenesis}

A medical legal assessment in cases of litigation for temporomandibular joint disorders of supposed iatrogenic is a difficult task to perform. The hypothesis of a causal link between a medical/dental act and the onset of TMD symptoms has to be verified by taking into account for some basic concepts about the etiology of these disorders (7).

Temporomandibular disorders recognize a multifactorial etiology in a biopsychosocial frame, with a multiplicity of factors (i.e. parafunctional

Artigo publicado na revista Tagete 2008; 14 (1)

2 TMD Clinic, Department of Maxillofacial Surgery, University of Padova, Italy 
activities, occlusal abnormalities, increased joint friction, psycho-affettive disorders) that may play a potential causal, predisposing, triggering or perpetuating role (8).

Unfortunately, usually little can be known about the relative role of these factors at the patient's level, to the point that the term "idiopathic" has been proposed to describe the origin of TMD symptoms in many cases (9).

\section{Diagnosis}

Due to uncertainties about their etiology, currently available TMD classifications are mainly symptoms' based (10), and standardized clinical assessments are the standard of reference for patients' evaluations among expert practitioners and academic authorities $(11,12)$

Indeed, there is currently agreement among scientists that the standard of care for TMD diagnosis is a thorough clinical examination performed according to a validated diagnostic scheme and reliable and repeatable techniques (13).

Available evidence suggests that a clinical evaluation performed by a trained investigator according to calibrated manoeuvres has a good diagnostic agreement with magnetic resonance (MR), which is the standard of reference among imaging techniques for the depiction of soft tissues, for at least the two main groups of joint disorders (disc displacements, inflammatory-degenerative disorders) (14,15).

There is agreement that the diagnostic process for temporomandibular joint disorders may be integrated with the adoption of appropriately selected imaging techniques but, by contrast, it has been demonstrated that there is no place for electronic devices in the diagnostic or treatment planning phases $(16,17)$.

\section{Treatment}

There is consensus in the scientific community that TMD treatment is mainly based on symptoms management rather than causal factors interception and elimination, due to the complex multifactorial etiopathogenesis which makes the establishment of a causal therapy difficult (18). The adoption of conservative treatment modalities is based on the assumption that nonreversible and invasive therapies are not indicated to treat symptoms in the absence of a well-identified pathogenetic pathway. The absence of a recognized causal therapy has led to the proposal of several treatment modalities for symptoms management, among which occlusal splints $(19,20)$, physiotherapy 
(21), behavioral and physical treatments (22), drugs (23-26), while surgery seems to be reserved to a minority of patients (27-33).

\section{latrogenic lesions}

Literature supporting the hypothesis that TMD symptoms occur after iatrogenic interventions is scarce, and the possibility of such an occurrence is infrequent, due to the large adaptation skills of the stomatognathic system, which allow achieving good therapeutic outcomes or maintaining a good balance with a simple high-prudence approach to TMD management or to complex rehabilitation treatments (34).

Nonetheless, extreme cases of under- or over-treatment may lead to iatrogenic lesions.

Examples of the former are cases of severe temporomandibular joint arthrosis that, if left untreated, may evolve to ankylosis and subsequent need for complex TMJ surgeries.

Case of overtreatment are unfortunately more frequent, and regard mainly the adoption of surgical techniques that were not indicated for the specific disorder or symptom referred by the patient, as in the case of TMJ surgeries for disk repositioning performed to solve a non-pathological joint click. Such interventions may hesitate in joint ankylosis, thus requesting drastic definitive interventions, such as total temporomandibular joint replacement $(35,36)$.

\section{Traumatic lesions}

Traumatic lesions to the temporomandibular joint may be the consequence of direct (i.e.: condylar fracture following a violent chin trauma) or indirect (temporomandibular joint effusion following a car accident cervical whiplash) trauma.

The effects of direct trauma on the temporomandibular joint are welldocumented in the literature, and depend upon the intensity, direction and area of the impact, ranging from mild contusions to severe and rarely described cases of condyle penetration into the middle cranial fossa $(37,38)$. Also, cases of post-traumatic ankylosis have been described in the literature, and surgical corrections are consequently needed (39).

Indirect traumas are often called into cause in claims for TMD damage. Some studies suggested the co-occurrence of a mandibular whiplash with a car-accident cervical whiplash, on the basis of the hypothesis that the extreme hypertranslation of the condyle out of the glenoid fossa might lengthen or 
even stretch the posterior attachment and the ligaments, both at the medial and lateral levels, thus predisposing to disk displacement and post-traumatic joint tenderness and effusion (40). Nonetheless, the existence of the so-called temporomandibular joint whiplash is still much debated (41).

\section{Conclusions}

A deep knowledge of the complex mechanisms that may lead to TMJ disorders has a basic importance for the interpretation of clinical findings at a patient level. Indeed, while direct trauma to the temporomandibular joint provoked easily objectivable injuries, the same is not true for cases of indirect trauma or iatrogenic events. In those cases, a medical legal assessment has to take into account for the current of care among diagnostic procedures (i.e. standardized clinical assessment, imaging techniques, no electronic devices) and rehabilitation protocols in both TMD and non-TMD subjects (i.e. highprudence, low-technology treatment plans).

\section{References}

1. McNeill C. History and evolution of TMD concepts. Oral Surg Oral Med Oral Pathol Oral Radiol Endod 1997; 83: 51-60.

2. Lobbezoo F, Drangsholt M, Peck C, Sato H, Kopp S, Svensson P. Topical Review: New Insights into the Pathology and Diagnosis of Disorders of the Temporomandibular Joint. J Orofac Pain 2004; 18: 181-91.

3. List T, Dworkin SF. Comparing TMD diagnoses and clinical findings at Swedish and US TMD center using Research Diagnostic Criteria for Temporomandibular Disorders. J Orofac Pain 1996; 10: 240-53.

4. Yap AJU, Dworkin SF, Chua EK, List T, Tan KBC, Tan HH. Prevalence of temporomandibular disorders subtypes, psycologic distress and psychosocial dysfunction in asian patients. J Orofac Pain 2003; 17: 21-8.

5. Manfredini D, Chiappe G, Bosco M. Research Diagnostic Criteria for Temporomandibular Disorders (RDC/TMD) axis I diagnosis in an italian patients population. J Oral Rehabil 2006; 33: 551-8.

6. Manfredini D, Bucci MB, Guarda-Nardini L. Medical legal aspects of temporomandibular disorders assessment. Cranio, submitted.

7. Goldstein BH. Medical legal considerations in temporomandibular disorders. Oral Surg Oral Med Oral Pathol Oral Radiol Endod 1999; 88: 395-9.

8. Greene C. The etiology of temporomandibular disorders: implications for treatment. J Orofac Pain 2001; 15: 93-105.

9. Woda $\mathrm{A}$, Pionchon P. Focus artiche: a unified concepì of idiopathic orofacial pain: clinical features. J Orofac Pain 1999; 13: 172-84. 
10. Okeson JP. Current terminology and diagnostic classification schemes. Oral Surg Oral Med Oral Pathol Oral Radiol Endod 1997; 83: 61-4.

11. Dworkin SF, LeResche L. Research diagnostic criteria for temporomandibular disorders: review, criteria, examinations and specifications, critique. J Craniomand Disord 1992; 6: 301-55.

12. American Academy of Orofacial Pain. Assessment of orofacial pain disorders. In: Okeson JP (ed). Orofacial pain: guidelines for assessment, diagnosis, and management. Chicago: Quintessence, 1996: 19-44.

13. McNeill C. Management of temporomandibular disorders: concepts and controversies. J Prosthet Dent 1997; 77: 510-22.

14. Manfredini D, Tognini F, Zampa V, Bosco M. Predictive value of clinical findings for temporomandibular joint effusion. Oral Surg Oral Med Oral Pathol Oral Radiol Endod 2003; 96: 521-6.

15. Orsini MG, Kuboki T, Terada S, Matsuka Y, Yatani H, Yamashita A. Clinical predictability of temporomandibular joint disc displacement. J Dent Res 1999; 78: 650-60.

16. Mohl ND. Reliability and validity of diagnostic modalilities for temporomandibular disorders. Adv Dent Res 1993; 7: 113-9.

17. Baba K, Tsukiyama Y, Clark GT. Reliability, validity and utility of various occlusal measurement methods and techniques. J Prosthet Dent 2000; 83: 83-9.

18. Goldstein BH. Temporomandibular disorders: a review of current understanding. Oral Surg Oral Med Oral Pathol Oral Radiol Endod 1999; 88: 379-85.

19. Dao TT, Lavigne GJ. Oral splints : the crutches for temporomandibular disorders and bruxism ? Crit Rev Oral Biol Med 1998; 9: 345-61.

20. Raphael K, Marbach JJ. Widespread pain and the effectiveness of oral splints in myofascial face pain. J Am Dent Assoc 2001; 132: 305-16.

21. Michelotti A, Parisini F, Farella M, Cimino R, Martina R. Fisioterapia muscolare in pazienti con disordini temporomandibolari. Studio clinico controllato. Minerva Stomatol 2000; 49: 541-8.

22. De Laat A, Stappaers K, Papy S. Counseling and physical therapy as treatment for myofascial pain of the masticatory system. J Orofac Pain 2003; 17: 42-9.

23. Dionne RA. Pharmacologic treatments for temporomandibular disorders. Oral Surg Oral Med Oral Pathol Oral Radiol Endod 1997; 83: 134-42.

24. Manfredini D, Romagnoli M, Cantini E, Bosco M. Efficacy of tizanidine hydrochloride in the treatment of myofascial face pain. Minerva Med 2004; 95: 165-71.

25. Dionne RA. Pharmacologic treatment of acute and chronic orofacial pain. Oral Maxillofac Surg Clin North Am 2000; 12: 309-20.

26. Plesh O, Curtis D, Levine J, Mccall WD. Amitriptyline treatment of chronic pain in patients with temporomandibular disorders. J Oral Rehabil 2000; 27: 834-41.

27. Dimitroulis G. The role of surgery in the management of disorders of the temporomandibular joint: a critical review of the literature. Part 1. Int J Oral Maxillofac Surg 2005; 34: 107-113.

28. Guarda-Nardini L, Masiero S, Marioni G. Conservative treatment of temporomandibular joint osteoarthrosis: intra-articular injection of hyaluronic acid. J Oral Rehabil 2005; 32: $729-34$. 
29. Guarda-Nardini L, Tito R, Staffieri A, Beltrame A. Treatment of patients with arthrosis of the temporomandibular joint by infiltration of hyaluronic acid: a preliminary study. Eur Arch Otorhinolaryngol 2002; 259: 279-84.

30. Mercuri LG. Considering total temporomandibular joint replacement. Cranio 1999; 17: 44-8.

31. Nitzan DW, Dolwick MF. Artrhroscopyc lavage and lysis of the TMJ: a change in perspective. J Oral Maxillofac Surg 1990; 48:798-801.

32. Guarda-Nardini L, Stifano M, Brombin C, Salmaso L, Manfredini D. A one year case series of arthrocentesis with hyaluronic acid injections for temporomandibular joint osteoarthritis. Oral Surg Oral Med Oral Pathol Oral Radiol Endod 2007; 103(6):e14-22.

33. Guarda-Nardini L, Manfredini D, Ferronato G. Temporomandibular joint total replacement prosthesis: current knowledge and considerations for the future. Int $\mathrm{J}$ Oral Maxillofac Surg 2007, in press.

34. Stohler C, Zarb G. On the management of temporomandibular disorders: a plea for low-tech, high-prudence therapeutic approach. J Orofac Pain 1999; 13: 255-61.

35. Guarda-Nardini L, Manfredini D, Berrone S, Ferronato G. Total temporomandibular joint prosthesis as a surgical option for severe mouth opening restriction. A case report of a bilateral intervention. Reumatismo 2007, in press.

36. Guarda-Nardini L, Manfredini D, Ferronato G. Total temporomandibular joint replacement: a clinical case with a proposal for post-surgical rehabilitation. J Craniomaxillofac Surg 2008, in press.

37. Ellis E, Throckmorton GS. Treatment of mandibular condylar process fractures: biological considerations. J Oral Maxillofac Surg 2005; 63(1): 115-34.

38. Goldberg MB. Posttraumatic temporomandibular disorders. J Orofac Pain 1999; 13(4): 291-4.

39. Manfredini D, Bucci MB, Guarda-Nardini L, Ferronato G. Temporomandibular joint bilateral post-traumatic ankylosis: a report of a case treated with interpositional arthroplasty. Minerva Stomatol 2007, in press.

40. Friedman MH, Weisberg J. The craniocervical connection: a retrospective analysis of 300 whiplash patients with cervical and temporomandibular disorders. Cranio 2000; 18: 163-7.

41. McKay DC, Christensen LV. Whiplash injuries of the temporomandibular joint in motor vehicle accidents: speculations and facts. $\mathrm{J} \mathrm{O}$

Resumo: Avaliação das lesões traumáticas e iatrogénicas da articulação temporo-maxilar As lesões traumáticas e iatrogénicas da articulação temporo-maxilar são pouco comuns. No entanto, a avaliação médico-legal destas situações é uma tarefa complexa que deve ter em conta os elevados níveis de evidência apresentados na literatura que respeita a estas perturbações temporo-maxilares e dentárias.

As perturbações da articulação temporo-maxilar têm uma etiopatogenia multifactorial que deve ser diagnosticada de acordo com as classificações estandardizadas de referência. Esta metodologia pode ser útil para os casos mais complexos, como os das perturbações das 
articulação temporo-maxilar que possam surgir na sequência de situações de iatrogenia ou de traumatismo indirecto.

Palavras-chave: Lesões iatrogénicas; lesões traumáticas; lesões da articulação temporo-maxilar.

Summary: Temporomandibular joint injury assessment: traumatic and iatrogenic lesion Iatrogenic or traumatic lesions to the temporomandibular joint are an uncommon finding. Nonetheless, a medical legal appraisal in those situations is a complex task that has to take into account for the current best level of evidence in the TMD/dental literature.

Disorders of the temporomandibular joint have a complex multifactorial etiopathogenesis and must be diagnosed according to referenced standardized classifications. Such an approach may be helpful in the evaluation of the most complex medical legal cases, as in the case of temporomandibular disorders symptoms supposedly occurring after iatrogenic events or indirect trauma.

Key-words: Iatrogenic lesions; traumatic lesions; temporomandibular joint injury

Résumé: Évaluation des lésions traumatiques et iatrogéniques de l'articulation temporomaxillaire Les lésions iatrogéniques et traumatiques de l'articulation temporomaxillaire sont peux communes. Cependant, l'évaluation médico-légale de ces situations est une tâche complexe qui doit tenir compte des niveaux d'évidence les plus élevés dans la littérature concernant ces pertubations temporomaxillaires et dentaires.

Les perturbations de l'articulation temporomaxillaire a une éthiopathogénèse multifactorielle et doit être diagnostiquée selon les classifications standardisées de référence. Cette méthodologie peut être utile à l'évaluation des cas les plus complexes, comme ceux des perturbations de l'articulation temporomaxillaire qui se produiraient après des situations de iatrogénie ou de traumatisme indirect.

Mots-clés: Lésions iatrogéniques; lésions traumatiques; lésions de l'articulation temporomaxillaire.

\section{Pedido de separatas:}

DANIELE MANFREDINI

info@improntesrl.it 